University of South Florida

DIGITAL COMMONS

Digital Commons @ University of

@ UNIVERSITY OF SOUTH FLORIDA

South Florida

KIP Articles

KIP Research Publications

January 1994

\title{
Geologic framework and hydrogeologic characteristics of the Edwards Aquifer outcrop, Comal County, Texas
}

T. A. Small

J. A. Hanson

Follow this and additional works at: https://digitalcommons.usf.edu/kip_articles

\section{Recommended Citation}

Small, T. A. and Hanson, J. A., "Geologic framework and hydrogeologic characteristics of the Edwards Aquifer outcrop, Comal County, Texas" (1994). KIP Articles. 2136.

https://digitalcommons.usf.edu/kip_articles/2136

This Article is brought to you for free and open access by the KIP Research Publications at Digital Commons @ University of South Florida. It has been accepted for inclusion in KIP Articles by an authorized administrator of Digital Commons @ University of South Florida. For more information, please contact digitalcommons@usf.edu. 


\section{GEOLOGIC FRAMEWORK AND HYDROGEOLOGIC CHARACTERISTICS OF THE EDWARDS AQUIFER OUTCROP, COMAL COUNTY, TEXAS}

\section{U.S. GEOLOGICAL SURVEY}

Water-Resources Investigations Report 94-4117

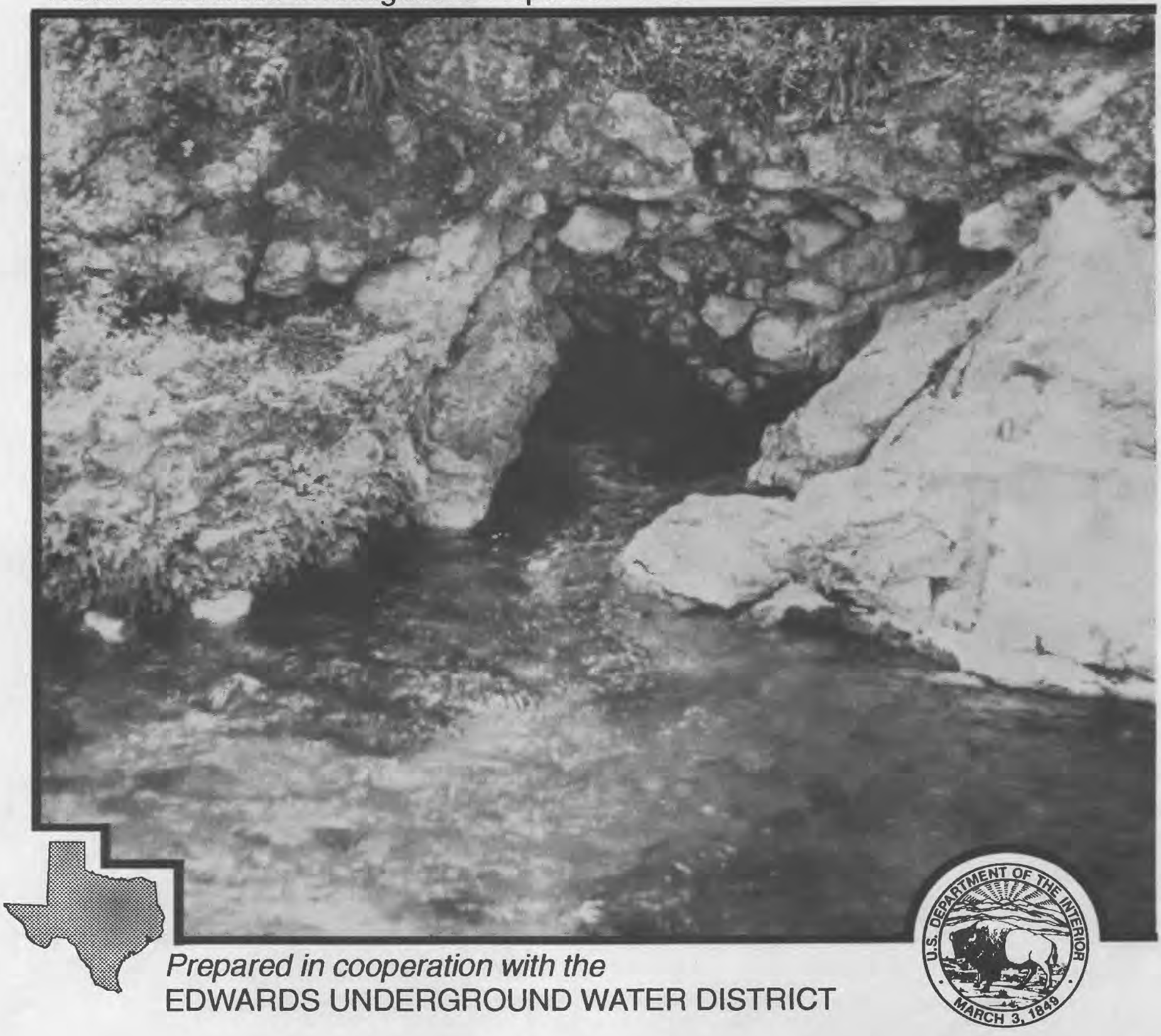


Cover photograph: One of the spring orifices at Comal Springs discharging a combined flow of 336 cubic feet per second, March 1994. Photograph by Ted A. Small. 


\section{GEOLOGIC FRAMEWORK AND HYDROGEOLOGIC CHARACTERISTICS OF THE EDWARDS AQUIFER OUTCROP, COMAL COUNTY, TEXAS}

By Ted A. Small and John A. Hanson

\section{U.S. GEOLOGICAL SURVEY}

Water-Resources Investigations 94-4117

Prepared in cooperation with the EDWARDS UNDERGROUND WATER DISTRICT 


\section{U.S. DEPARTMENT OF THE INTERIOR \\ BRUCE BABBITT, Secretary \\ U.S. GEOLOGICAL SURVEY \\ Gordon P. Eaton, Director}

Any use of trade, product, or firm names is for descriptive purposes only and does not imply endorsement by the U.S. Government.

For additional information write to:

istrict Chief

U.S. Geological Survey 8011 Cameron Rd.

Austin, TX 78754-3898
Copies of this report can be purchased from:

U.S. Geological Survey

Earth Science Information Center

Open-File Reports Section

Box 25286, Mail Stop 517

Denver Federal Center

Denver, CO 80225-0046 


\section{CONTENTS}

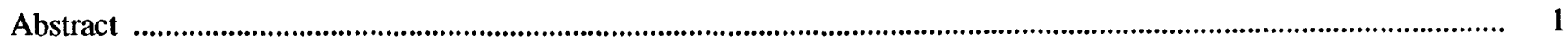

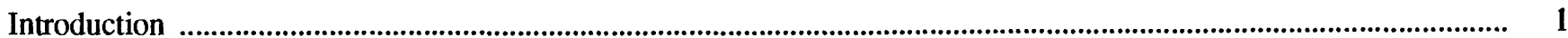

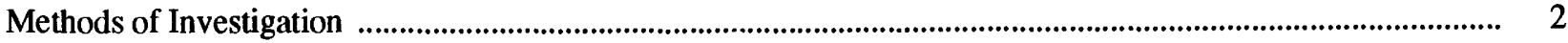

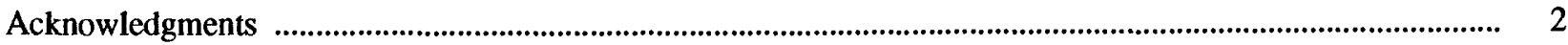

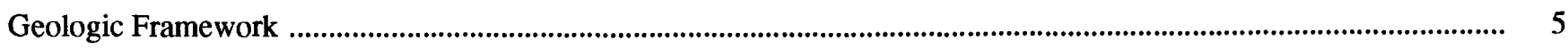

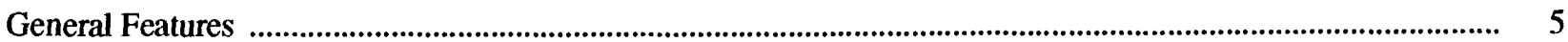

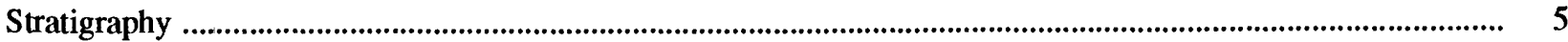

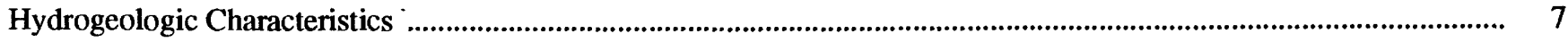

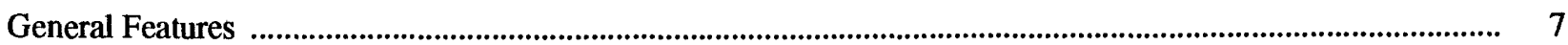

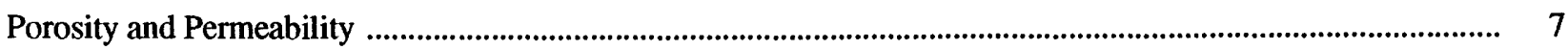

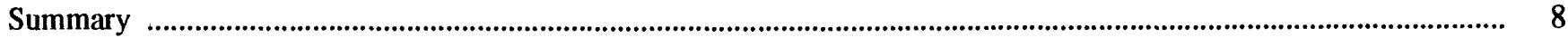

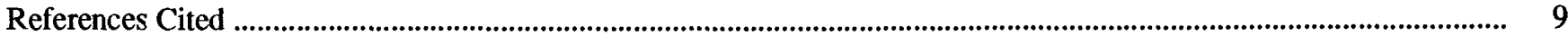

\section{PLATE}

[Plate is in pocket]

1. Map showing hydrogeologic subdivisions of the Edwards aquifer outcrop, Comal County, Texas.

\section{FIGURE}

1. Map showing location of the study area

\section{TABLE}

1. Summary of the lithologic and hydrologic properties of the hydrogeologic subdivisions of the Edwards aquifer outcrop, Comal County, Texas

\section{CONVERSION FACTORS AND VERTICAL DATUM}

\begin{tabular}{rll}
\hline Multiply & By & To obtain \\
\hline foot $(\mathrm{ft})$ & 0.3048 & meter \\
foot per mile (ft/mi) & 0.1894 & meter per kilometer \\
inch per year (in/yr) & 25.4 & millimeter per year \\
mile (mi) & 1.609 & kilometer \\
\hline
\end{tabular}

Sea level: In this report, "sea level" refers to the National Geodetic Vertical Datum of 1929--a geodetic datum derived from a general adjustment of the first-order level nets of the United States and Canada, formerly called Sea Level Datum of 1929. 


\title{
Geologic Framework and Hydrogeologic Characteristics of the Edwards Aquifer Outcrop, Comal County, Texas
}

\author{
By Ted A. Small and John A. Hanson
}

\section{Abstract}

All of the hydrogeologic subdivisions within the Edwards aquifer outcrop in Comal County have some porosity and permeability. The most porous and permeable appear to be hydrogeologic subdivision VI, the Kirschberg evaporite member of the Kainer Formation; hydrogeologic subdivision III, the leached and collapsed members, undivided; and hydrogeologic subdivision II, the cyclic and marine members, undivided, of the Person Formation. The two types of porosity in the Edwards aquifer outcrop are fabric selective, which is related to depositional or diagenetic elements and typically exists in specific stratigraphic horizons; and not fabric selective, which can exist in any lithostratigraphic horizon. Permeability, the capacity of porous rock to transmit water, depends on the physical properties of the rock such as pore size, shape, distribution, fissuring, and dissolution.

Two faults, Comal Springs and Hueco Springs, completely, or almost completely, offset the Edwards aquifer along much of their respective traces across Comal County. Porous and permeable Edwards aquifer limestone is juxtaposed against impermeable upper confining units in these areas. These faults completely, or almost completely, offset the Edwards aquifer and are thought to be barriers or partial barriers to groundwater flow where the beds are juxtaposed.

In Comal County, the Edwards aquifer is probably most vulnerable to surface contamination in the rapidly urbanizing areas on the Edwards aquifer outcrop. Possible contamination can result from spills, leakage of hazardous materials, or runoff onto the intensely faulted and fractured, karstic limestone outcrops characteristic of the recharge zone.

\section{INTRODUCTION}

The Edwards aquifer, located in the Lower Cretaceous Kainer and Person Formations of the Edwards Group (Rose, 1972) and the overlying Georgetown Formation, is one of the most highly permeable and productive aquifers in Texas (Maclay and Small, 1984). The dissolution-modified, faulted limestone aquifer (Buszka and others, 1990) is the sole source of public-water supply for San Antonio (ninth largest city in the United States) and is the major source of water for Comal County.

Most recharge to the Edwards aquifer is west of Bexar County (fig. 1). Rivers and rainfall runoff in normally dry streambeds cross Edwards aquifer outcrops (the recharge zone) in the Balcones fault zone and lose much, if not all, of their flow to faults, fractures, sinkholes, and caves in the outcrop. After entering the aquifer, the water moves east to points of discharge in Bexar County (mostly municipal wells) and then northeast, parallel or almost parallel to the northeast-trending Balcones faults into Comal and Hays Counties, where it is discharged by wells and by springs. Additional recharge to the Edwards aquifer is from Edwards aquifer outcrops in the Balcones fault zone in northerm Bexar County and southern Comal and Hays Counties. The rugged, scenic, limestone hills of the Edwards aquifer outcrops are the site of rapidly encroaching residential and commercial development. The aquifer possibly can be contaminated by spills, leakage of hazardous materials, or runoff from the rapidly developing urban areas that surround, or are built on, the intensely faulted and fractured, karstic limestone outcrops characteristic of the recharge zone. Furthermore, some of the hydrogeologic subdivisions that compose the Edwards aquifer are inherently more porous than 
others, and the areas where the most porous subdivisions crop out are susceptible to transmitting contaminants into the aquifer. According to Buszka (1987, p. 2), "carbonate aquifers, such as the Edwards, are readily susceptible to ground-water contamination where the presence of pollutants coincides with the outcrop of the aquifer." In Comal County, the Edwards aquifer probably is most vulnerable to surface contamination in the rapidly urbanizing areas on the Edwards aquifer outcrop.

The U.S. Geological Survey, in cooperation with the Edwards Underground Water District, mapped the Edwards aquifer outcrop and described its hydrogeologic characteristics (porosity and permeability) to document conditions pertinent to movement and contamination of ground water. This report describes the geologic framework and the hydrogeologic characteristics of the Edwards aquifer outcrop in Comal County.

\section{Methods of Investigation}

The Edwards aquifer outcrop was mapped using the hydrogeologic subdivisions (table 1) modified from Maclay and Small (1976). Names of the corresponding members follow the stratigraphic nomenclature of Rose (1972) for the Kainer and Person Formations of the Edwards Group on the San Marcos platform (fig. 1). The carbonate-rock classification system of Dunham (1962) was used for the lithologic descriptions. Member, hydrogeologic subdivision, and porosity/permeability type were determined at the outcrop. The porosity type follows the sedimentary carbonate classification system of Choquette and Pray (1970). Fault locations and configuration of the members of the Edwards aquifer outcrop in Comal County are shown on plate 1 .

Recent aerial photographs were used to locate roads and excavations that might provide outcrop exposures for field examination and for orientation in the morphologically similar Edwards aquifer outcrops. In addition, stratigraphic information was ascertained by inspection of surficial expressions and features as indicated by the following examples. The basal nodular member of the Kainer Formation supports a dense growth of juniper and oak trees and can be recognized on aerial photographs by the dark trace that encompasses the hills of the overlying dolomitic member. The dolomitic member of the KainerFormation, which caps several hills in north-central Comal County, can be identified on aerial photographs by the pattern of con- centric rings formed by the sparse vegetation growing on the differentially weathered limestone. The regional dense member of the Person Formation can be recognized on aerial photographs by small, light to almost white areas.

Well logs and geologic map data were collected, compiled, and used in mapping the hydrogeology of the study area. The thicknesses of the hydrogeologic subdivisions that compose the Edwards aquifer were determined from well logs in and adjacent to the aquifer outcrop in Comal County. The upper member of the Lower Cretaceous Glen Rose Limestone, the lower confining unit (table 1), was mapped adjacent to the Edwards aquifer outcrop along the northwestern boundary of the study area (pl. 1). The upper confining units, which include the Upper Cretaceous Del Rio Clay, Buda Limestone, Eagle Ford Group, Austin Group, and Navarro and Taylor Groups, undivided, were mapped along the southeastem boundary of the study area.

Faults were identified in the field by stratigraphic displacement and characteristics related to faulting, such as zones of fault gouge composed of soils that greatly resemble caliche, or relatively thick, vein-like masses of euhedral to subhedral calcite crystals. The strata were steeply inclined in some localities as the result of drag-folding related to faulting. Cedar elm trees that tend to grow along faults, perhaps as a result of enhanced downward movement of water along the fault planes, also were used as a mapping aid.

\section{Acknowledgments}

Special thanks are extended to W.G. Stein, LBGGuyton Associates, who recently mapped the Edwards aquifer outcrops in Bexar County and part of southwestern Comal County. W.G. Stein identified some of the geologic features in Comal County while mapping in the field. Thanks also are extended to Dr. J.E. Wilson, chairman of the Department of Geology (retired), University of Michigan, for his helpful comments during a tour of the study area. The authors also thank those property owners who supplied information, aided in the collection of field data, and granted permission to enter their property. 


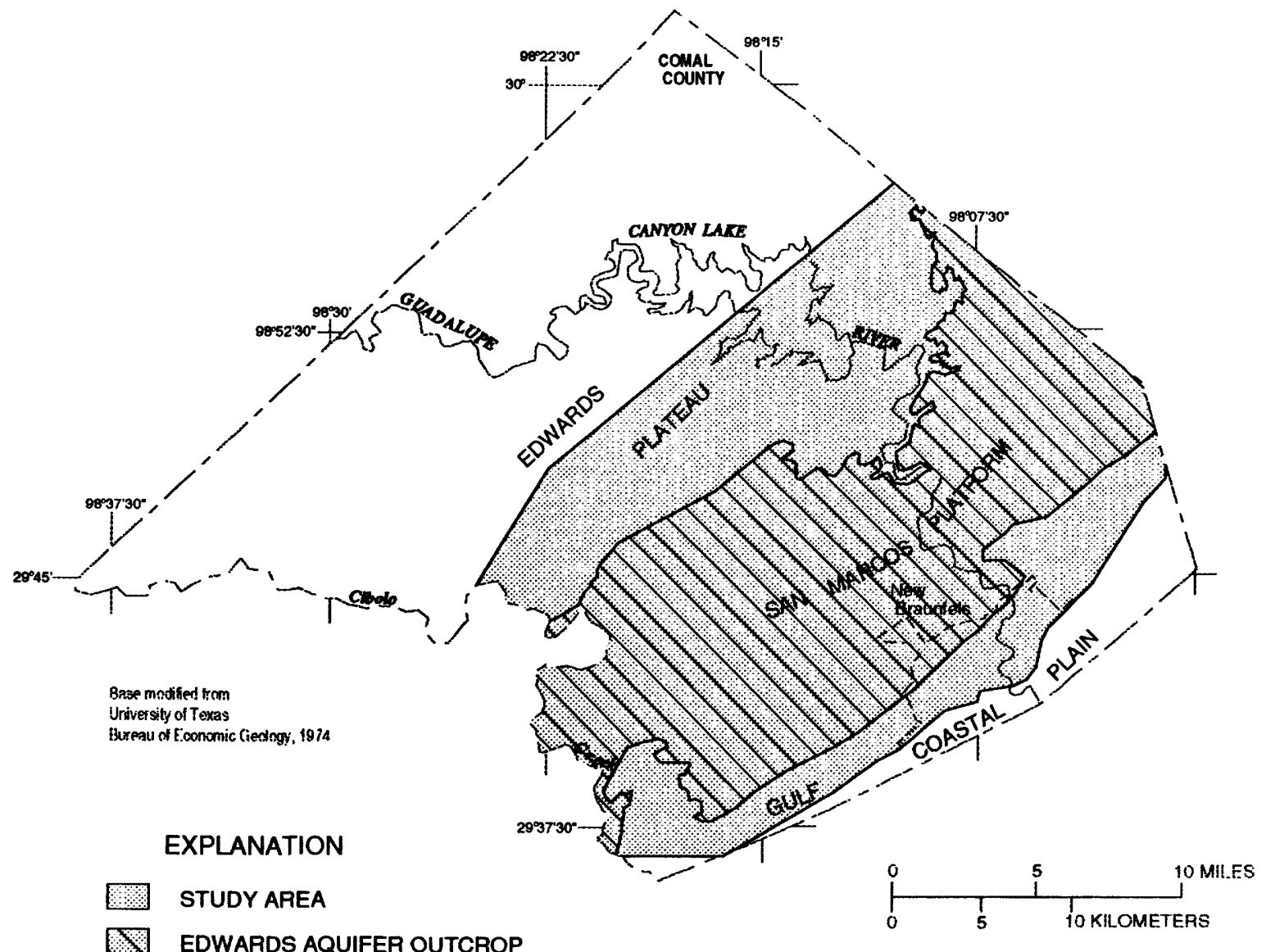

I. EDWARDS AQUIFER OUTCROP

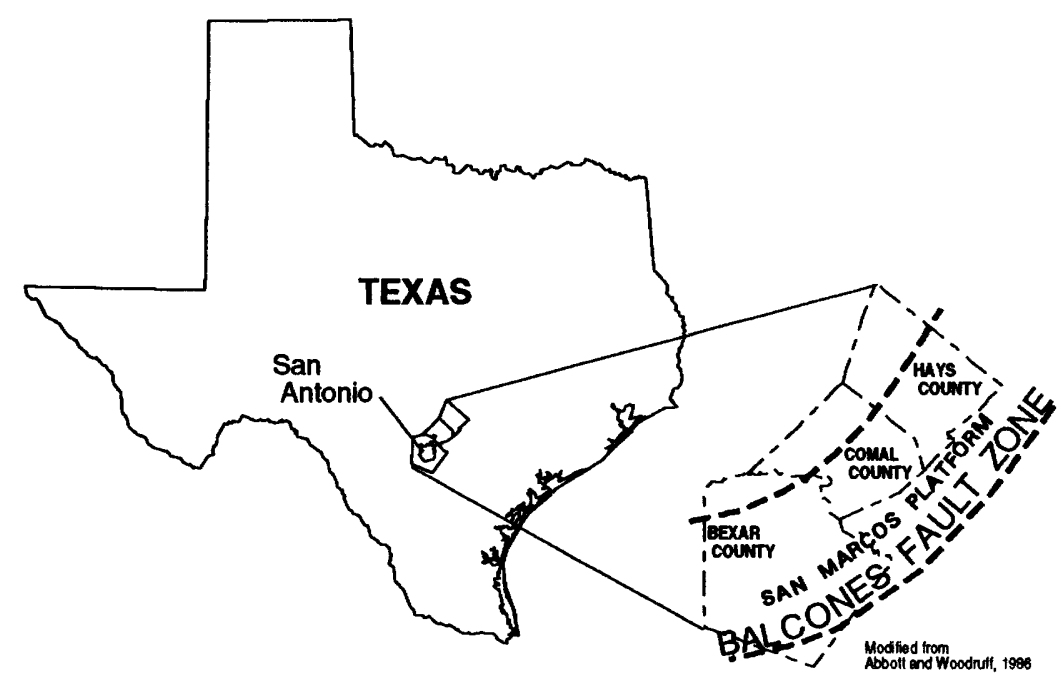

Figure 1. Location of the study area. 
Table 1. Summary of the lithologic and hydrologic properties of the hydrogeologic subdivisions of the Edwards aquifer outcrop, Comal County, Texas

[Hydrogeologic subdivisions modified from Maclay and Small (1976); groups, formations, and members modified from Rose (1972); lithology modified from Dunham (1962); and porosity type modified from Choquette and Pray (1970). CU, confining unit; AQ, aquifer]

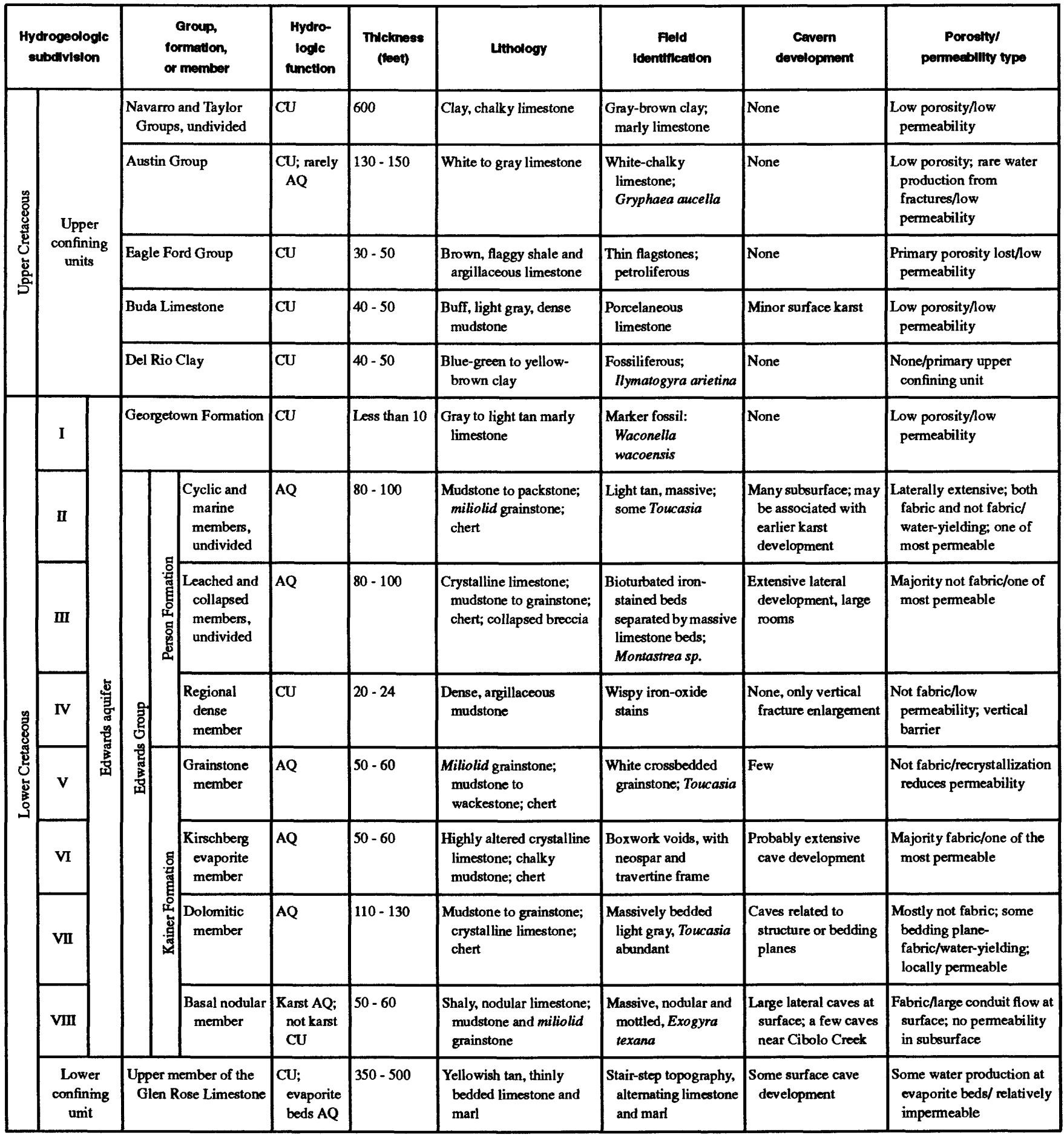




\section{GEOLOGIC FRAMEWORK}

\section{General Features}

A regional dip of $15 \mathrm{ft} / \mathrm{mi}$ to the southeast for Cretaceous strata on the Edwards Plateau (fig. 1) in Comal County was reported by George (1952, p. 33). Comal County is on the crest of the San Marcos platform as mapped by Rose (1972, fig. 16). Northeasttrending faults of the Balcones fault zone cross the entire county, but are more numerous in the southeastem part of the county. According to George (1952, p. 29), the most noticeable fault in the Balcones fault zone, Comal Springs fault (pl. 1), forms a prominent part of the escarpment separating the Gulf Coastal Plain from the Edwards Plateau.

Balcones faults are normal and mostly down-tothe southeast (down-to-the Gulf Coast); however, a few faults are down-to-the northwest. The faults are nearly vertical (George, 1952), en echelon, and some completely offset the Edwards Group (Maclay and Small, 1984, p. 33). The pattern of northeast-trending faults is broken occasionally by north to northwest-trending cross-faults. W.G. Stein and G.B. Ozuna (LBG-Guyton Associates and U.S. Geological Survey, respectively, oral commun., 1991) noted that many faults in the recharge area of the Edwards aquifer show little, if any, topographic relief. Grimshaw and Woodruff (1986, p. 72) stated, "the fact that fault traces are not at all influenced by topography indicates that all faults are vertical, or nearly so." The similar weathering properties of the juxtaposed limestones probably caused an erosional smoothing of the terrain.

Geomorphic expression of faulting on the upthrown fault blocks is indicated on topographic maps by the branching of subsequent valleys normal to the consequent valleys, forming a "T-square" morphology of the valleys. The formation of the consequent valleys resulted from the drop in base level of the downthrown block, which initiated headward erosion on the escarpment. The development of the subsequent valleys possibly is the result of faults structurally weakening the consequent valley slopes creating the T-square pattern normal to the natural course of headward erosion (Thombury, 1962). Later faults that cut across the Guadalupe River (pl. 1) contributed to the youthful meandering of the river as well as creating small rapids where faults cross the river.

The five primary faults in Comal County are Comal Springs, Hueco Springs, Bat Cave, Bear Creek, and Hidden Valley (pl. 1). Two of these faults, Comal Springs and Hueco Springs, juxtapose Edwards aquifer limestone against beds of the upper confining unit along much of their trace across Comal County, and are thought to be barriers or partial barriers to groundwater flow where the beds are juxtaposed.

\section{Stratigraphy}

The Edwards Group is about $\mathbf{4 4 0} \mathrm{ft}$ thick in Comal County (table 1) and consists of limestone with chert in the form of nodules, lenses, and thin discontinuous beds. George (1952, p. 23) reported that chert was not evident in any other Cretaceous strata in Comal County. This information is useful when mapping the outcrop of the Edwards Group. Massive, nodular limestone beds at the lower part of the Kainer Formation conformably overlie the alternating marl and limestone beds of the üpper member of the Glen Rose Limestone in Comal County (George, 1952, p. 21). The upper member of the Glen Rose Limestone is identified by its characteristic stair-step topography caused by the differential weathering of the nonresistant marl and resistant limestone and dolomite beds (Stricklin and others, 1971, p. 23).

The Kainer and Person Formations of the Edwards Group were divided into seven informal members by Rose (1972). These members were further modified by Maclay and Small (1976) into eight informal hydrogeologic subdivisions, which include the overlying Georgetown Formation. The Georgetown Formation is not known to yield water in the study area. However, because well drillers historically have considered the Georgetown Formation to indicate the top of the Edwards aquifer, the formation is considered part of the aquifer. Except for the Georgetown Formation, the strata that compose the Edwards aquifer were deposited in shallow to very shallow marine waters (Rose, 1972; J.E. Wilson, University of Michigan, oral commun., 1992) and reflect depositional environments resulting from slight changes in water level, water chemistry, temperature, and circulation. These factors caused subtle to not-so-subtle variations in the overall lithology of the various members and some variations within the individual members.

The Kainer Formation is about $260 \mathrm{ft}$ thick within Comal County (table 1). The lithology of the Kainer Formation ranges from mudstone to miliolid grainstone to crystalline limestone. The lowermost unit, the basal nodular member, is about $50 \mathrm{ft}$ thick and 
is generally a marly, nodular limestone and some miliolid grainstone. The fossil oyster Exogyra texana is scattered erratically throughout the lower part of the member. Kastning (1986, p. 95) noted that in a small area near Cibolo Creek (pl. 1), extensive passages in Natural Bridge Caverns, Bat Cave, and Double Decker Cave have developed in the Walnut Formation, which is equivalent to the basal nodular member on the San Marcos platform. These passages indicate local strong lithologic control in this member (Kastning, 1986). The next higher member, the approximately 110 -ft-thick dolomitic member, is mostly dense crystalline limestone with occasional zones of grainstone and layers of variably burrowed mudstone. Chert nodules and thin discontinuous beds of chert are scattered throughout the member. Rudists, usually Toucasia, are common locally near the top of the member.

The Kirschberg evaporite member is about $50 \mathrm{ft}$ thick and consists mostly of crystalline limestone and chalky mudstone with chert nodules and lenses. This member lacks the collapse features common to the Kirschberg evaporite on the Edwards Plateau, which might indicate that less evaporite was deposited on the San Marcos platform.

The grainstone member overlies the Kirschberg evaporite member and is the uppermost member of the Kainer Formation. The grainstone member is about $50 \mathrm{ft}$ thick and primarily is dense, tightly cemented miliolid grainstone; however, patches of mudstone to wackestone are scattered throughout. Chert nodules exist in this member, but are rare. Locally, Toucasias are common near the top of the member. Chondradonta, a distinctive, thick-shelled pelecypod, is in approximately the same stratigraphic interval as the Toucasias, but is not common.

The Person Formation (Rose, 1972, p. 19) is about $180 \mathrm{ft}$ thick in Comal County (table 1). The lithology of the Person Formation ranges from variably burrowed mudstone to grainstone to crystalline limestone. The regional dense member is the lowermost member of the Person Formation, consisting of dense, argillaceous mudstone. The grainstone member (Kainer Formation) and the regional dense member (Person Formation) combined is a distinctive mapping horizon of the Edwards Group outcrop on the San Marcos platform.

The leached and collapsed members, undivided, overlie the regional dense member and were mapped as one because they could not be distinguished as separate members. These members consist of variably burrowed mudstone to grainstone and intervals of crystalline limestone; chert lenses are common as well. The collapsed zones common in this member probably were caused by the collapse of overlying limestone into the voids created by early dissolution of the thin evaporite layers and lenses (Rose, 1972, p. 55). The lower part of the cyclic and marine members, undivided, were difficult to distinguish from the upper part of the leached and collapsed members, undivided, because of their similar lithology.

The cyclic and marine members, undivided, also were mapped as one unit. According to Rose (1972, p. 71), the cyclic member and part of the marine member were eroded from the axis of the San Marcos platform prior to the deposition of the Georgetown Formation. The remaining part of the marine member consists of medium thick to thick beds of mudstone and fossiliferous packstone, as well as lenses of miliolid grainstone and chert nodules. Locally, Toucasia type rudists are common near the contact of the marine member with the overlying Georgetown Formation. The leached, collapsed, cyclic, and marine members of the downdip Person Formation cannot be recognized in the shallow San Marcos platform area (Rose, 1972, p. 25). Young's (1986, p. 65) inference that, "karstification of the Person Formation was much more thorough than karstification of the Kainer Formation," was confirmed in this study.

The Georgetown Formation, which overlies the Edwards Group, was deposited on the eroded surface of the Person Formation in deeper water than was characteristic for most of the Edwards Group deposition (Rose, 1972, p. 71). The Georgetown Formation is generally a marly limestone and usually contains the brachiopod Waconella wacoensis, formerly Kingena wacoensis (Roemer), which is an excellent marker fossil for the Georgetown Formation. Exposures of the unevenly bedded Georgetown Formation are rare, and where observed, are usually less than $10 \mathrm{ft}$ thick.

The Upper Cretaceous Del Rio Clay, Buda Limestone, Eagle Ford Group, Austin Group, and Navarro and Taylor Groups, undivided, overlie the Georgetown Formation (table 1). The Del Rio Clay is a dark bluegreen to yellow-brown, variably gypsiferous clay commonly containing pecten-type fossil clams and an abundance of the fossil oyster Ilymatogyra arietina, formerly Exogyra arietina (Roemer). These fossil oysters are known locally as "rams horns." The Buda Limestone is a dense, variably nodular, sublithographic or "porcelaneous" (Sellards and others, 1933, p. 397), 
light gray mudstone, commonly containing calcispheres and tiny calcite-filled fractures. The Eagle Ford Group overlies the Buda Limestone and is a calcareous, sandy shale unit. The flaggy, sandy shale erodes easily and usually only thin patches crop out. Some of the flags (thin brittle slabs) emit a petroliferous odor when fractured. Because the Eagle Ford Group is dark brown in the subsurface, local water-well drillers commonly refer to this shale as lignite.

The Austin Group, which overlies the Eagle Ford Group, is a chalky, variably marly, generally fossiliferous limestone, commonly containing the fossil oyster Gryphaea aucella. The Navarro and Taylor Groups, undivided, overlie the Austin Group; however, in the study area, they are present only on the downthrown side of the Comal Springs fault. The Navarro Group consists of calcareous clay that is silty locally. The Taylor Group consists of calcareous clay, chalk, and clayey chalky limestone. The Navarro and Taylor Groups, undivided, were mapped as one because of their similarities in the upper clay section (William F. Guyton and Associates, 1979, p. 19).

Field identification of the various members in the Kainer and Person Formations was based on their characteristic lithologies and fossils (table 1). Red clay soil that resembles the Pleistocene-age "terra rossa" described by Young (1986, p. 63), which represents diagenetically altered paleosols, commonly is evident in outcrops of the Edwards Group, but rarely in the Glen Rose Limestone or in the clays or limestones of the upper confining units. According to Young (1986, p. 65), the red clay soil indicates that lithology was important in the development of Central Texas terra rossa. Red clay soil was observed more often in the Person Formation than the Kainer Formation, but locally it is common in the Kirschberg evaporite member and has been reported in core and drill cuttings in the Kainer Formation.

The grainstone member of the Kainer Formation was identified by its very light gray, almost white color, and distinctive miliolid grainstone spar-matrix characteristic. Although grainstone lenses occasionally are identified in the dolomitic member and a few other members, the lenses are not common. The regional dense member is identified by its characteristically light tan color, argillaceous limestone, and wispy ironoxide stains. Stock tanks frequently are built in this dense, argillaceous member because it will hold water. Borrow pits for road bases also are common in this member. The regional dense member is the key marker bed for determining stratigraphic position in the Edwards Group outcrops. Because of the lithologic similarities between the leached and collapsed members, undivided, and the cyclic and marine members, undivided, of the Person Formation, the contact between the two sometimes is difficult to determine. In these areas, the approximate stratigraphic thickness of the unidentified unit was used to identify the unit and locate the approximate contact. A unique colonial coral, tentatively identified as Montastrea sp. (Finsley, 1989), was observed in the lower to middle part of the leached and collapsed members, undivided, and could serve as a guide fossil.

\section{HYDROGEOLOGIC CHARACTERISTICS}

\section{General Features}

Major factors controlling porosity and permeability in the Edwards aquifer outcrop are faulting, stratification, and karstification-a form of diagenesis resulting from extensive dissolution of limestone. Zones of faulted, fractured limestone, along with layers of burrowed, vuggy, and occasionally cavemous limestone are common in the Edwards aquifer outcrop.

The karst features of the Edwards Group limestone in Comal County are characterized by resistant terrain of dense limestone, sparsely dotted with sinkholes, dolines, and caves. The dry-subhumid climate (Thornthwaite, 1952) (rainfall $32.34 \mathrm{in} / \mathrm{yr}$; Brown and others, 1992, table 1) is not favorable for rapid karst development. According to W.G. Stein and G.B. Ozuna (LBJ-Guyton Associates and U.S. Geological Survey, respectively, oral commun., 1991), the presence of caves in the Edwards Group limestone in Bexar County is random and the morphology is controlled by the local stratigraphy. These same conditions probably are true also in Comal County.

\section{Porosity and Permeability}

According to Choquette and Pray (1970, p. 212), porosity in sedimentary carbonates is either fabric selective or not fabric selective. Fabric selective porosity is related directly to the depositional or diagenetic fabric elements of a sediment and typically is controlled by lithostratigraphic horizon. Not fabric selective porosity is not related to depositional or diagenetic elements of a sediment and can exist in any lithostratigraphic horizon. 
Choquette and Pray (1970, p. 222) designated seven types of carbonate porosity that are "extremely common and volumetrically important." Five of these (interparticle, intraparticle, intercrystalline, moldic, and fenestral) generally are fabric selective, and two (fracture and vuggy) are not fabric selective. According to Choquette and Pray (1970, p. 223-224), breccia porosity is a type of interparticle porosity and can be either fabric selective or not fabric selective. Other types of porosity that are in the Edwards aquifer outcrop are channel and cavern, both of which are not fabric selective, and burrow, which can be either fabric selective or not fabric selective. Choquette and Pray (1970, p. 245) proposed that "channel" be used to describe "markedly elongated pores or irregular openings with a marked elongation in one or two dimensions relative to a third dimension."

Permeability is the capacity of a porous rock to transmit water. According to Ford and Williams (1989, p. 130), permeability depends on the physical properties of the rock, particularly pore size, shape, and distribution. Ford and Williams (1989, p. 150) further state that, "As a consequence of the effects of fissuring and differential solution, permeability may be greater in some directions than in others as well as in certain preferred stratigraphic horizons." The eight hydrogeologic subdivisions of the Edwards aquifer, the names of the corresponding members, and the type of porosity and permeability observed in the field within the subdivisions are discussed in ascending order.

Hydrogeologic subdivision VIII (basal nodular member) has interparticle porosity but little permeability in the miliolid grainstone and the nodular limestone beds. Cavern porosity and permeability associated with caves in this subdivision is located in several caves in a small area near Cibolo Creek. This subdivision is locally, but not regionally, porous or permeable.

Hydrogeologic subdivision VII (dolomitic member) has little visible porosity or permeability in the dense crystalline limestone. Interparticle (breccia) porosity and permeability and fracture porosity and permeability associated with faulting is common locally. Vuggy porosity and permeability also is common locally in the burrowed zones.

Hydrogeologic subdivision VI (Kirschberg evaporite member) generally has common to abundant intercrystalline porosity in the chalky mudstone, and locally abundant vuggy porosity and permeability probably associated with faulting and early removal of evaporites (Maclay and Small, 1976). This subdivision has both fabric selective and not fabric selective porosity, and appears to be the most porous and permeable subdivision in the Kainer Formation.

Hydrogeologic subdivision V (grainstone member) has widely separated interparticle and intraparticle porosity and little permeability in the dense, tightly cemented miliolid grainstone, and local fracture porosity and permeability associated with faulting. Otherwise, this subdivision has little porosity or permeability.

Hydrogeologic subdivision IV (regional dense member) has little porosity or permeability except for some fracture porosity and permeability associated with faulting. This subdivision probably is the least porous or permeable subdivision and locally may be a confining unit within the Edwards aquifer.

Hydrogeologic subdivision III (leached and collapsed members, undivided) has vuggy and burrow porosity and permeability associated with burrowed zones; breccia and cavern porosity and permeability associated with collapsed zones resulting from dissolution of evaporites; and fracture porosity and permeability associated with faulting. Hueco Springs (pl. 1) issue from alluvium overlying this subdivision. Many of the group of springs known as Comal Springs issue along the Comal Springs fault from openings believed to be near the base of subdivision III. This probably is the most porous and permeable of the subdivisions and, thus, the most susceptible to contamination from surface sources.

Hydrogeologic subdivision II (cyclic and marine members, undivided) has moldic and vuggy porosity and permeability associated with fossiliferous zones, and fracture porosity and permeability associated with faulting. Field observations indicate that this subdivision has only slightly less porosity and permeability than subdivision III.

Hydrogeologic subdivision I (Georgetown Formation) has few, thin, isolated outcrops and almost no visible porosity or permeability. This subdivision is not water-yielding in Comal County and it serves as one of the upper confining units in the artesian zone of the Edwards aquifer (George, 1952, p. 24).

\section{SUMMARY}

The Edwards aquifer is the sole source of publicwater supply for San Antonio and is the major source of water for Comal County. The aquifer primarily consists of dissolution-modified, faulted limestone. The 
Edwards aquifer is recharged in its outcrop area in the Balcones fault zone.

In Comal County, the Edwards aquifer probably is most vulnerable to surface contamination in the rapidly urbanizing areas on the Edwards aquifer outcrop. Possible contamination can result from spills, leakage of hazardous materials, or runoff onto the intensely faulted and fractured, karstic limestone outcrops characteristic of the recharge zone.

The Kainer and Person Formations of the Edwards Group and the overlying Georgetown Formation compose the Edwards aquifer. The Kainer and Person Formations consist of seven informal members. These members generally coincide with eight informal hydrogeologic subdivisions of the aquifer, which include the overlying Georgetown Formation. Some formation members are similar in lithology and appearance, whereas others are more distinctive.

Northeast-trending faults of the Balcones fault zone cross Comal County and are more numerous in the southeastem part of the county. Comal Springs fault, one of the five primary faults that cross the county, forms a prominent part of the escarpment separating the Edwards Plateau from the Gulf Coastal Plain. Comal Springs issue from openings believed to be near the base of subdivision III along the Comal Springs fault. Hueco Springs fault, another of the five primary faults, and Comal Springs fault juxtapose the Edwards aquifer limestone against the overlying upper confining units along much of their traces across Comal County. These faults completely, or almost completely, offset the Edwards aquifer and are thought to be barriers or partial barriers to ground-water flow where the beds are juxtaposed.

The major factors controlling porosity and permeability in the Edwards aquifer outcrop are faulting, stratification, and karstification. Karst features in this area, which can greatly enhance the porosity and permeability, include sinkholes, dolines, and caves. The two types of porosity in the Edwards aquifer outcrop are fabric selective, which is related to depositional or diagenetic elements and typically exists in specific stratigraphic horizons; and not fabric selective, which can exist in any lithostratigraphic horizon. The capacity of porous rock to transmit water depends on the physical properties of the rock such as pore size, shape, distribution, fissuring, and dissolution. The Edwards aquifer hydrogeologic subdivisions VI (Kirschberg evaporite member), III (leached and collapsed members, undivided), and II (cyclic and marine members, undivided, of the Person Formation) appear to be the most porous and permeable; subdivision III probably is the most susceptible to contamination from surface sources. Hydrogeologic subdivision VIII (basal nodular member) has cavem porosity and permeability near Cibolo Creek, but regionally is not porous.

\section{REFERENCES CITED}

Abbott, P.L., and Woodruff, C.M., Jr., eds., 1986, The Balcones escarpment, central Texas: Geological Society of America, p. 1-14.

Brown, D.S., Gilhousen, J.R., and Nalley, G.M., 1992, Compilation of hydrologic data for the Edwards aquifer, San Antonio area. Texas, 1991, with 1934-91 summary: Edwards Underground Water District Bulletin 51, $169 \mathrm{p}$.

Buszka, P.M., 1987, Relation of water chemistry of the Edwards aquifer to hydrogeology and land use, San Antonio region, Texas: U.S. Geological Survey WaterResources Investigations Report 87-4116, 100 p.

Buszka, P.M., Zaugg, S.D., and Werner, M.G., 1990, Determination of trace concentrations of volatile organic compounds in ground water using closed-loop stripping, Edwards aquifer, Texas: Bulletin of Environmental Contamination and Toxicology, p. 507-515.

Choquette, P.W., and Pray, L.C., 1970, Geologic nomenclature and classification of porosity in sedimentary carbonates: American Association of Petroleum Geologists Bulletin, v. 54, no. 2, p. 207-250.

Dunham, R.J., 1962, Classification of carbonate rocks according to depositional texture, in Classification of Carbonate Rocks Symposium: American Association of Petroleum Geologists Memoir 1, p. 108-121.

Finsley, Charles, 1989, A field guide to fossils of Texas: Austin, Texas Monthly Press, $189 \mathrm{p}$.

Ford, D.C., and Williams, P.W., 1989, Karst geomorphology and hydrology: London, Chapman and Hall, $601 \mathrm{p}$.

George, W.O., 1952, Geology and ground-water resources of Comal County, Texas: U.S. Geological Survey WaterSupply Paper 1138, $126 \mathrm{p}$.

Grimshaw, T.W., and Woodruff, C.M., Jr., 1986, Structural style in an en echelon fault system, Balcones fault zone, central Texas--geomorphologic and hydrologic implications, in Abbott, P.L., and Woodruff, C.M., Jr., eds., The Balcones escarpment, central Texas: Geological Society of America, p. 71-76.

Kastning, E.H., 1986, Cavern development in the New Braunfels area, Central Texas, in Abbott, P.L., and Woodruff, C.M., Jr., eds., The Balcones escarpment, central Texas: Geological Society of America, p. 91100.

Maclay, R.W., and Small, T.A., 1976, Progress report on geology of the Edwards aquifer, San Antonio area, 
Texas, and preliminary interpretation of borehole geophysical and laboratory data on carbonate rocks: U.S. Geological Survey Open-File Report 76-627, 65 p.

1984, Carbonate geology and hydrology of the Edwards aquifer in the San Antonio area, Texas: U.S. Geological Survey Open-File Report 83-537, 72 p.

Rose, P.R., 1972, Edwards Group, surface and subsurface, central Texas: Austin, University of Texas, Bureau of Economic Geology Report of Investigations 74, 198 p.

Sellards, E.H., Adkins, W.S., and Plummer, F.B., 1933, The geology of Texas, v. 1, Stratigraphy: Austin. University of Texas, Bureau of Economic Geology Bulletin 3232, $1,007 \mathrm{p}$.

Stricklin, F.L., Jr., Smith, C.I., and Lozo, F.E., 1971, Stratigraphy of Lower Cretaceous Trinity deposits of central Texas: Austin, University of Texas, Bureau of Economic Geology Report of Investigations 71, $63 \mathrm{p}$.
Thornbury, W.D.; 1962, Principles of geomorphology: New York, Wiley, $617 \mathrm{p}$.

Thornthwaite. C.W., 1952, Evapotranspiration in the hydrologic cycle, in The physical and economic foundation of natural resources. v. II, The physical basis of water supply and its principal uses: U.S. Congress, House of Representatives, Committee on Interior and Insular Affairs, p. 25-35.

University of Texas, Bureau of Economic Geology, 1974, Geologic atlas of Texas, San Antonio sheet: Scale $1: 250,000$.

William F. Guyton and Associates, 1979, Geohydrology of Comal, San Marcos, and Hueco Springs: Texas Department of Water-Resources Report 234, 85 p.

Young, Keith, 1986, The Pleistocene terra rossa of central Texas, in Abbott, P.L., and Woodruff, C.M., Jr., eds., The Balcones escarpment, central Texas: Geological Society of America, p. 63-70. 


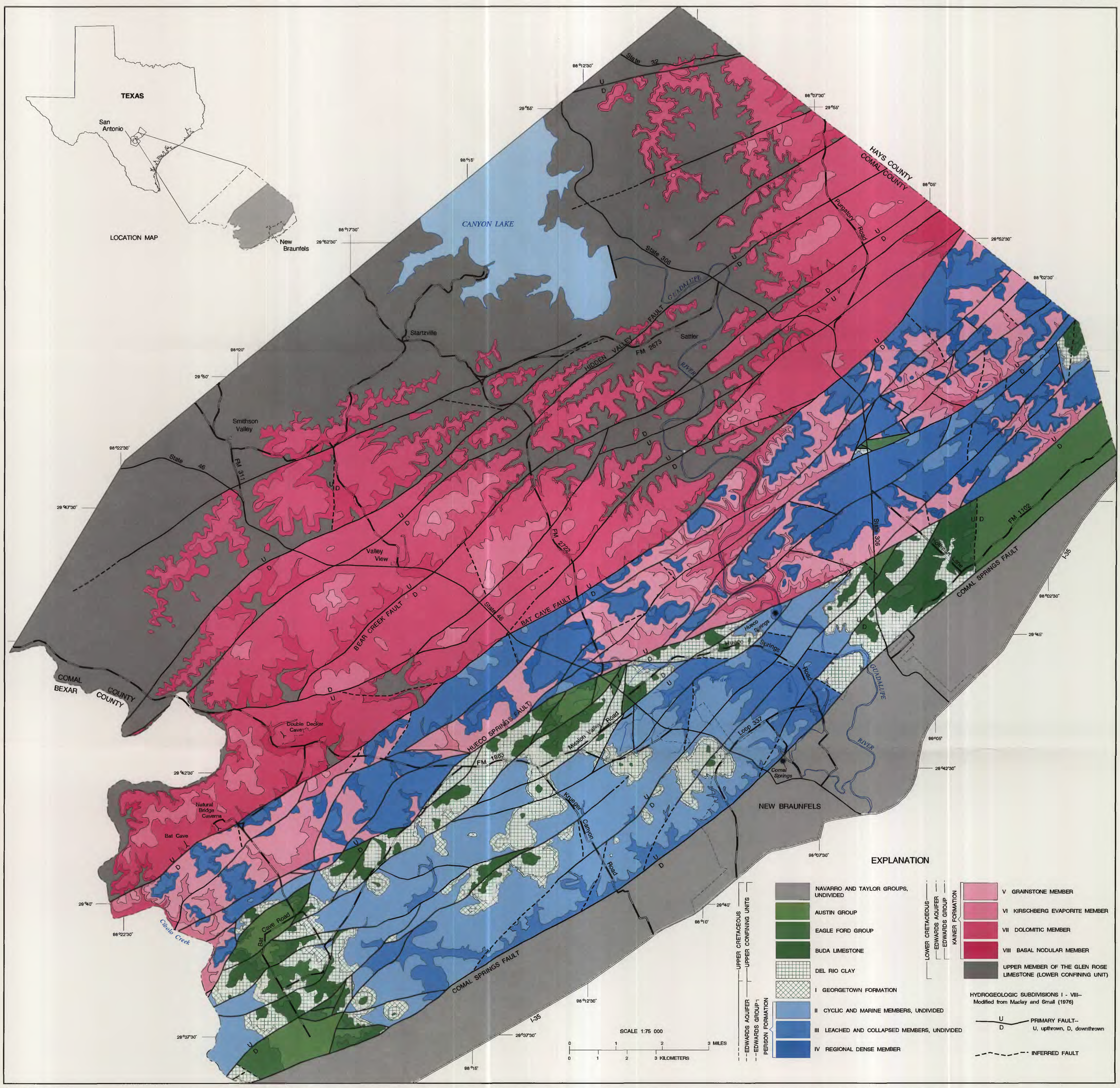

